www.noz.ue.wroc.pl

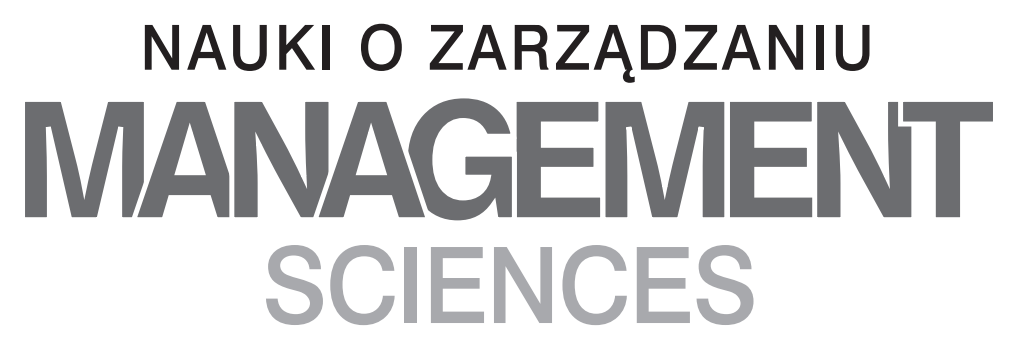

ISSN 2080-6000

e-ISSN 2449-9803

1 (30) 2017

\title{
PROJECT TEAMS: SELECTED TOPICS ${ }^{1}$ ZESPÓŁ PROJEKTOWY: WYBRANE TEMATY
}

\author{
Renata Winkler \\ Cracow University of Economics, e-mail: winklerr@uek.krakow.pl
}

\begin{abstract}
Summary: The purpose of this study is to present and analyze those topics that are crucial from the point of view of the functioning of project teams. The article presents issues referring to the improvement and development of a project team. It includes following deliberations on the selection of team members, building the team, training and leadership. The article was drawn up on the basis of the review of the literature on the subject.
\end{abstract}

Keywords: project team, leadership, training.

\begin{abstract}
Streszczenie: Sukces zespołu projektowego zależy od tego, jak tworzące go jednostki będą ze sobą funkcjonować i kooperować. Przyjmuje się, że w pełni rozwinięty zespół nie tylko ma autonomię, ale teżczynnie reguluje kierunek swoich działań (jest samozarządzający i samosterujący). Celem niniejszego opracowania jest prezentacja i analiza węzłowych z punktu widzenia funkcjonowaniem interdyscyplinarnych zespołów projektowych kwestii, takich jak: dobór członków zespołu, budowanie zespołu, szkolenia i przywództwo. Artykuł przygotowano na podstawie przeglądu literatury przedmiotu.
\end{abstract}

Słowa kluczowe: zespół projektowy, przywództwo, szkolenie.

${ }^{1}$ The publication was financed from the funds granted to the Faculty of Management of the Cracow University of Economics, within the framework of the subsidy for the maintenance of research potential in 2016. 


\section{Introduction}

Contemporary economic conditions result in the fact that the use of group forms of work organization is becoming more and more common. This is justified, among others, by the fact that the objectives determined by the organization to be implemented (tasks) remain unattainable in individual actions due to their complexity. It is also necessary to emphasize the fact that ensuring the flexibility of actions on the part of the organization often requires the organization to undertake ad hoc and non-standard actions which, as a result, deepens the specific "liquidity of demand" on the part of the organization for specific skills of its employees (both in terms of the type of these skills and with regard to the method and the period in which they are used). The actual growth in the practical interest in project management as well as related matters regarding team leadership is reflected in the publications related to management. Much attention is paid to the knowledge, competence, suitability, skills, motivation and commitment of the people forming the team as well as to the cooperation within the team.

The project team's success depends to a large extent on how the units forming the team function and cooperate with one another. In the case of a project team, improvement (and the subsequent development of this team) should be understood, first of all, in terms of the growth in the efficiency of the team's operation. The following are recognized as the key issues in team improvement in this aspect: the selection of team members, team building, the team's training and the development of leadership [Unsworth, West 2003, p. 378]. The purpose of this study is to present and analyze these topics, which are crucial from the point of view of the functioning of project teams. The study was drawn up on the basis of the review of the literature on the subject.

\section{Group, team and project team}

The notions "group" and "team" are clearly separated in studies related to management.

A group is most often defined as at least two people who interact with one another so that they mutually affect each other, and (what is important) these people do not need to pursue a mutual objective [Griffin, Moorhead 2011, pp. 240-241].

The notion of a team, in turn, refers to such a group which meets all the following conditions [Griffin, Moorhead 2011, pp. 268-269]:

- This group is not too numerous. The level of interrelations and interactions proper from the point of view of the effectiveness of work may only occur in a small community. The majority of methodologies assume the functioning of a team usually consisting of 3-5 people (up to 8-9 people under special circumstances.

- The competences and skills of the group members are complementary towards one another.
- The members of this group have a mutual objective, and they all remain involved in its execution and they jointly bear the responsibility for this execution. It is also assumed that a fully developed team not only has autonomy but also actively adjusts the direction of its actions and is thus self-managing and self-controlling. Not every group is thus a team, although every team is a group. The transformation of a group into a team requires, first of all, the shaping and strengthening of bonds between the team members (building an appropriate level of consistency between them) [Barinaga 2007, p. 337]. This is not possible without the development of communication and cooperation processes within the group [Paul, Cadle, Thomas 2012, p. 25].

The notion "project team" is used to identify a formal group of people appointed to execute a specific project. A project is a separate and unique (one-time) enterprise executed within a certain organization that is different from the routine actions executed within this organization. To be more specific - it is an enterprise which consists of a sequence of unique, and complex tasks connected with one another with a mutual objective as well as intended for execution according to previously specified requirements, within a specified deadline and within an agreed budget [Wysocki, McGarry 2005, p. 47; Kisielnicki 2011, p. 15]. This means, at the same time, that a project team is dissolved when the project ends (the team operates in "a period"). The time interval in which this type of team operates depends on the level of the complexity of the project adopted for execution (this may take several months or several years). The specific nature of the objective adopted for execution results in the fact that there are teams working in one place and time ("the same time, the same place"), dispersed in terms of space (the same time, different place) or teams which additionally involve the asynchronous execution of tasks ("the same place, different time" - or - "different time, different place"). Except for the first case, the members of such teams communicate with one another mainly with the use of electronic means of communication.

The composition of the project team is subordinated to the execution of specific enterprises. The project team involves people whose participation in the project is desired due to their knowledge, competences, skills and/or experience (this takes place regardless of whether they are full-time employees, contractors, or the former and the latter participate in the project). Therefore, people who never cooperated with one another before, who have different education and professional experience, sometimes also a different cultural origin (project teams are relatively often teams diverse in cultural terms) are in many cases recruited for a project team. It is a commonly adopted practice that some people are involved in the team's work on a project only at a specific stage of this work (e.g. on request). As a result, both the composition of the team throughout the project may change (this may also apply to the so-called basic composition of the project team), and the structure of the project team 
is sometimes unstable. It should also be emphasized that there are also cases when a single employee participates in several different teams, in the execution of various projects, at the same time. In particular, this is true with regard to a person who serves as the manager of the project team. In many cases the project team manager supervises the work of more than one team at the same time (additionally, the manager also often remotely manages the team's work). In practice, there are also no topdown guidelines as to the size of the team. The project team may have several people (3-9), more than ten, or even several dozen people.

\section{Selection of project team members}

In the context of the specific nature of the operation of the project teams discussed above, it is particularly important to note the fact that not every outstanding specialist is fit to be a project team member. It is also worth mentioning that, according to the assumption of the majority of methodologies, in order to guarantee the highest effectiveness of operation, the number of people in the project team should range from within 3-5, exceptionally (under special circumstances) up to 8-9 people [Litke 2007, p. 181].

When selecting people for the project, the people selected for such teams should accept the adopted objective, should be involved in its execution and should be jointly responsible for the obtained effects. The objective adopted for execution not only steers the actions of the entire team but is also the reason and justification for its existence (it also determines the time horizon of the team's duration). Therefore it is important to acquire people for the team who not only have the appropriate knowledge and skills but also: demonstrate orientation on the task (namely have the ability to adopt a task-oriented attitude), have high communication skills, and can also work in a team [Unsworth, West 2003, p. 378].

With regard to task orientation. The selection of project team members only in terms of their education and professional experience may, in consequence, contribute to a situation in which people begin to focus to a greater extent on the differences, barriers and unavoidable conflicts presented by multilateral and close cooperation (the responsibilities of each person in random cases should be smoothly taken over by other team members) rather than on the action itself. Practical experience indicates that if team members are characterized by task-based orientation, this contributes to the stabilization of the work of the entire group mainly because people with task-based orientation try to fight any possible difficulties as quickly as possible without debating them excessively and assigning disproportionately great importance to them.

In the context of communication competence. Ensuring communication characterized by high quality is invaluable for the proper operation of each team. The specific nature of the work in a project team requires a system for transferring information based on the reci- procity and universality of information. Furthermore, the effectiveness of the project's execution depends, to a large extent, on sharing knowledge within the project team. Knowledge as a resource does not have an impersonal nature. The processes of acquisition, distribution or exchange of knowledge take place in contact with people and require acts of communication. Therefore members of the project team should present an open communication attitude expressed in the readiness to transfer information obtained individually which is sought by other members of the team [Wasiela-Jaroszewicz 2008, pp. 123-124]. Furthermore, the degree of openness of communication flows shapes the level of people's commitment to the organizational process of seeking and solving problems [Romanowska 2001, p. 43]. A conscious commitment, communication openness and carefulness are the grounds for good dialogue. Potential project team members should also be characterized by well-developed communication competences, so they should fluently use the base language for cooperation, be able to initiate and maintain communication interactions, adequately choose means and channels of communication, formulate the message according to social rules valid in communication interaction (choosing both linguistic and non-linguistic means of expression according to the situation), in an ordered, clear (understandable), unambiguous manner, and have the ability to exert interaction impact on communication interaction partners desired from the point of view of effectiveness [Winkler 2004, pp. 1266-1267], and in addition should be able to listen and aim at explaining any emerging discrepancies or misunderstandings.

The composition of the team may be improved by properly shaping the profiles of the required competences of the project team members, adequately choosing the selection criteria and improving the methods of selection. If the context of the discussed topics takes into account the desired ability to work in a team which, being an extensive competence, includes a number of skills such as: communication skills, building relations with other people, stress management, pursuit of outcome, orientation on actions, motivating oneself and others [Marzec], we may say that the acquisition of the appropriate people for projects is a greater challenge than the classic recruitment process.

\section{Building the project team}

At the beginning of the cooperation the project team is a group, not a team. A group of individuals who begin working for the execution of the project's mutual objective. A group which needs to pass through certain phases of development in order to be transformed into a team². In the first stage, people involved in the group behave definitely moderately aiming at becoming familiar with one another and trying to assess what the actual terms of cooperation are. As a result, their behavior which is more 
toned-down and more polite than usual hides the differences and possible disappointments. In the next phase, we are dealing with undertaking bolder and bolder attempts to see to what extent the standards they were convinced were binding, actually exist. The units also aim at identifying (or strengthening) their position, and a network of informal interrelations starts to emerge. In the next phase, the standards determining the manner of cooperation between people in this group are finally constituted and internalized and the structure of this group is finally determined. The scope of loyalty of the group's members towards one another is shaped at the same time. The group reaches maturity and the energy of the group members is focused to achieve the assumed objective because the group members perform their assigned roles and execute the assigned tasks. The group is "ready" to become a team.

The concept of team building was developed in the 1960s [Payne 2001, p. 4] from social psychology, in connection with the wave of interest in the process of group dynamics and the popularization of sensitivity training. Team building was originally dedicated to the improvement of relations within the group. Team building thus applies to forming team processes, integrating team members and building a clear, motivating vision of teamwork. This area is particularly important when people who have never cooperated with one another before are employed to the project team, or the team's composition changes throughout the project's duration, or particular members are geographically separated (spatial dispersion of the team and the resulting lack of direct cooperation face to face), or the work of particular team members is asynchronous in terms of time or it is necessary to create a very numerous team.

Team building involves the execution of various actions making it possible to achieve such a level of the group's integration with a mutual objective so that it is transformed into a team. Although team building includes such shaping of the group and the group process structure so as to create commitment, bonds and to strengthen mutual trust between people, it is used, first of all, to improve the efficiency of the team's work. It is not only about building "the spirit of teamwork" or social integration itself [Weingart et al. 2005, p. 96]. Team building involves focusing mutual effort on coordinating resources owned by the group to pursue a mutual objective. The objective of the team is clarified and unambiguously specified throughout team building, and the structure of team roles is selected and stabilized. It is assumed that team building: supports the process of group decision-making, enables the integration of individual objectives with group objectives, harmonizes cooperation, reduces the level of conflicts in the team, fosters a higher level of motivation, fosters the adequate assigning of roles in the team, strengthens bilateral communication (manifest and open communication is of crucial importance for team building), strengthens the sense of respon- sibility and makes it possible to build the team's own culture (see: [Tanke 2001, p. 212; Parker 2010, pp. 2-3]). It is accepted that team-building sessions bring better results if they are run by external coaches rather than the project manager [Payne 2001, p. 3].

The six following phases may be basically distinguished when taking actions focused on team building [Payne 2001, pp. 4-5]:

- the identification of needs,

- the acquisition of commitment,

- the assessment of needs and the expression of opinions,

- conducting team-building sessions,

- the implementation of results,

- the assessment of effects.

The following should be defined in the phase of identifying needs: the team's mission, the styles of leadership, the attitude of units towards one another, the atmosphere of work, the group's development phase, the implemented objectives, as well as the formal organization of work (including the binding procedures), the styles of leadership, the attitude of units towards one another. It is worth answering the following questions to identify and assess the needs [Adeniyi 2007, p. 67]: "Do the team members understand and accept the group's objectives? Do particular group members have individual hidden objectives (not shared by other members of the group) which may affect group achievements and/or reduce the commitment of these people? Is the leader's role carried out adequately? How are decisions made in the group? Do the group members have respect for one another? Do the group members trust one another? What emotions do they have towards one another?". With regard to which area in the team friction appears (conflicts become visible)? - if the team operates within an organization, the following question as well - What relations link the team with other organizational units? It is worth emphasizing that building an appropriate level of consistency requires building an atmosphere of mutual respect of the team members towards one another.

The team-building sessions may take very diverse forms. Their duration may also be diverse. Team-building sessions lasting 1-2 days bring particularly measurable benefits. In the case of a geographically dispersed team or when the project requires a change in the team's composition, integrating meetings with a top-down specified structure used only for the group members to become familiar with one another are invaluable (they are necessary, although they obviously are not sufficient. Spatial unity, temporal synchronicity and a stable composition of the group substantially support not only the process of social integration, but the team building as well).

The implementation of people joining the group throughout the project's duration into the team's work and integrating them within the group is a separate problem. The institution of a ghost is a solution found quite often in the practice of project groups (this is a person

${ }^{2}$ These phases in the Tuckman model are defined as: (1) the forming phase, (2) the storming phase, (3) the norming phase, (4) the performing phase [Nelson, Quick 2008, p. 205]. 
introducing a new person to work who "accompanies" a new member of the team for some time) or a supervisor (a delegated person to whom a new member may go to with a request for necessary information/explanations).

\section{Training the project team}

Training is used to prepare the human factor to function efficiently under new conditions. Training includes intentional and systematic actions aimed at supporting the learning of training participants, supplementing or deepening their knowledge, modeling their skills as well as appropriate attitudes and competences to shape the desired suitability with regard to the probable behavior of these people in specified circumstances (also for new training participants). Training makes it possible to understand certain phenomena and dependences, learn proper methods/schemes of conduct in certain situations as well as acquire some experience in controlled "safe" conditions. This is also true when the training does not provide new or original content from the point of view of people participating in the training. The training enables the formation of change in the employees themselves and in the methods of their operation due to the extraction, naming and arranging the knowledge already possessed by the participants and thus training involves added value.

Training may be closed (intended only for the employees of a specific organization and designed in terms of the requirements and needs of this organization), or open with the subject matter and form specified in advance by the training company. Open training includes the recruitment of participants coming from various organizations [Łaguna 2004, pp. 17-18]. The specific nature of work in a project team results in the fact that it is worth preferring those methods of improving qualifications which are associated with the place of work and develop interaction skills at the same time [Listwan 2011 , p. 125]. The importance of communication training should also be appreciated because: first, properly shaped communication competences of the team members are extremely desired; second, the implementation of communication processes strictly depends on one obtaining, creating, extracting, consolidating, codifying, transferring and reducing knowledge, and the processes of acquisition, distribution or exchange of knowledge take place in contact with people and require acts of communication); third, "communication errors" are an obstacle in obtaining the actual involvement of employees in actions undertaken by the organization and reduce the effectiveness of using complex forms of their interaction and cooperation.

The duration of training depends on the adopted program/substantive scope. This may either be a workshop lasting 1.5 hours or a regular training lasting several days (or weeks) for several hours a day. For purely practical reasons, it is recommended that the program scope of training is determined after: (1) recognizing and diagnosing the type of problem areas the specific training is to solve, (2) determining the priorities for the training as well as (3) determining the objectives of this training. It is important that the substantive scope of the training (its content) is not too wide ${ }^{3}$ but it should be diverse at the same time. It should also be emphasized that transferring only the theory, with regard to the majority of issues presented during the training, proves useful only for people who already have some experience in a given scope [Landis, Bhawuk 2004, p. 455]. In the case of people without experience, it is recommended to organize training with the behavioral component (e.g. simulation, exercise). This results from the essence of the process of acquiring competences which comes down to achieving three levels of knowledge: declarative (see what), procedural (see how), tacit [Landis, Bhawuk 2004, pp. 455-457].

The method of conducting the training should depend both on the content of the training and on the size of the group. Practical reasons support the fact that the most diverse methods and techniques as possible should be used to execute the content of the training, including those with a form assuming the active incorporation of participants in specially prepared model interactions. Contact with various forms and channels of transferring knowledge makes it possible to accelerate the acquisition of experience. The group of the most verified and the most effective training methods includes: a lecture, a presentation, a discussion, a session of group problem solving, an analysis of critical events, role playing as well as a simulation.

A wide range of training courses is difficult to obtain in a project team if the schedule is tight. However, their value should be appreciated. This applies, in particular, to training: (1) making it possible to maintain rights (or extend qualifications), (2) related to updating knowledge on legal regulations related to the area of the project group's professional activity, (3) related to updating knowledge on this type of the company's operations for which the client is willing to pay, (4) shaping competences related to learning, critical analysis of knowledge and creativity, (5) focused on developing teamwork skills. If we want the training to meet the designated role in the team (in this case, a project team) and make it possible to obtain the expected results, it is worth (see: [Hyla 2007, p. 26; Jemielniak 2008, p. 146; Kossakowska, Sołtysińska 2002, p. 14; Evans 2005, pp. 115-116]):

1) properly ensuring the motivation of the target training participants,

2) avoiding training in a fully remote manner,

3) building a training program focused on acquiring and developing a certain type of competences ${ }^{4}$,

4) ensuring that the training is constructive and not incidental ${ }^{5}$,

${ }^{3}$ An excessive quantity of provided content makes it significantly harder to distinguish content significant from the point of view of the performed work from secondary content. 
5) closing the training program ${ }^{6}$,

6) developing a system of strengthening the training effects as part of the company's daily practice,

7) obtaining the full support of the management for the training

At the same time it seems justified to leave the project team employees not only with the possibility to choose the topic of the training, the scope in which it is to be conducted within the selected topic or the form of its organization, but also to include these employees in designing, creating and even implementing the training itself.

\section{Leadership in the project team}

The essence of leadership is defined as exerting influence on a community of people in order to achieve a mutual objective. The effectiveness of leadership depends to a large extent on whether and what possibilities of creating conditions encouraging active involvement in achieving mutual objectives are possessed by the person exerting the influence [Pocztowski 1996, p. 82]. This depends, among others, on the composition of the team, with whom and where this team cooperates, what types of tasks it is to execute, and what is the quality of relation between the leader and particular members of the team and the entire team as a whole. It is also important how this team's work is organized in legal and technical terms. Therefore, the most important factors for the success of the team manager may be found both in the scope of the manager's suitability and the personal qualities, competences and professional experience possessed by the manager, as well as within strictly organizational factors (see: [Brake, Walker, Walker 1995, p. 230]).

In terms of the project manager's suitability and personal qualities, the following variables seem to be of particular importance in the context of the conducted analyses: the ability to exert influence, skills inspire others, being reliable (dependable), the team manager's personal involvement, persistence and determination, being capable of making objective assessments, being responsible as well as the ability to inspire trust [Winkler 2013, pp. 475-478]. It is by no means enough for a project team manager to pursue classic actions related to planning, determining tasks, coordinating, assessing and motivating. According to J.E. Adair [2008], ensuring the duration of the team and maintaining the mutual implementation of the task is not possible without giving instructions, supporting and giving example characterized by faith in people and faith in the possibility to achieve mutual success ${ }^{7}$.
In turn, when it comes to organizational variables, the following should be considered the most crucial for effective leadership within the project team: the ability to shape the distribution and amount of payroll elements of motivation by the manager, assigning the respective rights to the manager to guarantee relevant resources (measures) for the work of the manager's subordinated team, as well as the possibility to define the deadlines and particular stages of actions.

\section{Conclusion}

The discussed issues referring to project teams obviously do not cover the entire complexity of the issue, nor are they a ready-made recipe for solving all problems present in this type of teams. We should take into account numerous other aspects (for instance, conditions related to a possible language barrier between the team members or the diversity of personal qualities). However, there are strong indications as to the activities that can give real grounds to form a team which is effective and efficient in dealing with challenges during the implementation of a project. First, in the recruitment for project teams taking into account the assessment of the candidates' task-based attitude, their teamwork skills and communication skills. Second, the issue of methodical team building and emphasizing the need to create an atmosphere of mutual respect and trust in the team. Third, appreciating the value of training and organizing them according to premises which contribute to the implementation of the role assigned to them. Fourth, the adequate selection of the team manager along with granting the relevant resources to the manager.

\section{Literature}

Adair J.E., 2008, The Best of John Adair on Leadership and Management, Thorogood Publishing, London.

Barinaga E., 2007, Cultural diversity at work: National culture as a discourse organizing an international project group, Human Relations, no. 60(2).

Brake T., Walker D.M., Walker T.T., 1995, Doing Business Internationally. The Guide to Cros-Cultural Success, Irwin, New York.

Evans Ch., 2005, Zarządzanie wiedzą, Polskie Wydawnictwo Ekonomiczne, Warszawa.

Griffin R.W., Moorhead G., 2011, Organizational Behavior: Managing People and Organizations, Cengage Learning, Mason.

Hyla M., 2007,-Przewodnik po e-learningu, Wolters Kluwer Polska, Kraków.

Jemielniak D., 2008, Praca oparta na wiedzy: praca w przedsiębiorstwach wiedzy na przykładzie organizacji high-tech, Wydawnictwa Akademickie i Profesjonalne, Warszawa.

Kisielnicki J., 2011, Zarządzanie projektami. Ludzie - procedury wyniki, Oficyna Wolters Kluwer business, Warszawa.

\footnotetext{
${ }^{4}$ Isolated knowledge itself (which may be transferred as part of training) is depreciated relatively quickly. Therefore, from the point of view of the organization, it is still most reasonable to purchase and develop competences, as well as to shape an attitude related to the readiness to use the available knowledge and skills for the benefit of the organization.

${ }^{5} \mathrm{~A}$ single training course very rarely makes it possible to achieve the intended results.

${ }^{6}$ Interrupting or abandoning the continuation of an undertaken training process may not only make the effects of the training unpredictable, but it may also significantly reduce the level of the employees' motivation.

7 The effectiveness of instructions increases when they are performed in an optimistic manner, support requires full responsibility for the failure, and giving an example is ineffective if there is no credibility and honesty [Adair 2008].
} 
Kossakowska M., Sołtysińska I., 2002, Szkolenia pracowników a rozwój organizacji, Oficyna Ekonomiczna, Kraków.

Landis D., Bhawuk D.P., 2004, Synthesizing Theory Building and Practice in Intercultural Training, [in:] Handbook of Intercultural Training, D. Landis, J.M. Bennett., M.J. Bennett (ed.), Sage, Thousand Oaks-London-New Delhi.

Listwan T. 2011, Determinanty skuteczności kierowania zespołem projektowym, Przedsiębiorczość i Zarządzanie, t. XII, z. 14.

Litke H.D., 2007, Projektmanagement: Methoden, Techniken, Verhaltensweisen. Evolutionäres Projektmanagement, Hanser, München.

Łaguna M., 2004, Szkolenia. Jak je prowadzić, by..., Gdańskie Wydawnictwo Psychologiczne, Gdańsk.

Marzec M., Praca zespołowa a kompetencje osobowościowe kandydata, http://www.hrnews.pl/HRSupportArticle. aspx?id=80, 31.12.2016

Nelson D.L., Quick J.C., 2008, Understanding Organizational Behavior, Thomson South-Western, Mason.

Paul D., Cadle J., Thomas Ph., 2012, The Human Touch: Personal Skills for Professional Success, BCS: The Chartered Institute, Chippenham.

Payne V., 2001, The Team-Building Workshop: A Trainer's Guide, Amacom, New York.

Pocztowski A., 1996, Zarządzanie zasobami ludzkimi, Ossolineum, Wrocław-Warszawa-Kraków.

Romanowska M., 2001, Kształtowanie wartości firmy w oparciu o kapitał intelektualny, [in:] System informacji strategicznej, Borowiecki R., Romanowska M. (eds.), Difin, Warszawa.
Unsworth K.L., West M.A., 2003, Zespoły: wyzwania pracy w grupie, [in:] Psychologia pracy i organizacji, Chmiel N. (ed.), Gdańskie Wydawnictwo Psychologiczne, Gdańsk.

Wasiela-Jaroszewicz J., 2008, Komponenty procesu komunikacji w przedsiębiorstwie, [in:] Komunikacja wewnętrzna w organizacjach sieciowych, Lachiewicz S. (ed.), Monografie Politechniki Łódzkiej, Łódź.

Weingart L.R., Cronin M.A., Houser C.J.S., Cagan J., Vogel C.M., 2005, Functional Diversity and Conflict in Cross-functional Product Development Teams: Considering Representational Gaps and Task Characteristics, [in:] Understanding Teams, Neider L.L., Schreishman C. (eds.), Information Age Publishing, United States of America.

Winkler R., 2004, Uwarunkowania efektywnego komunikowania się, [w:] Strategie wzrostu wartości przedsiębiorstwa. Teoria i praktyka gospodarcza. Tom II, E. Urbańczyk E. (ed.), Zeszyty Naukowe Uniwersytetu Szczecińskiego, nr 378, Prace Instytutu Ekonomiki i Organizacji Przedsiębiorstw, nr 43, Wydawnictwo Kreos, Szczecin.

Winkler R., 2013, Przywództwo i komunikacja w zespole projektowym, Zeszyty Naukowe Uniwersytet Szczeciński, Finanse, Rynki Finansowe, Ubezpieczenia, no 786.

Wysocki R.K., McGary R., 2005, Efektywne zarządzanie projektami, Wydawnictwo Helion, Gliwice. 